\title{
Competitive Strategies of Thai Contractors in Construction Project Management in the CLMV Countries.
}

\author{
Boonyaperm, Thippawan ${ }^{\mathrm{a} *}$ \\ ${ }^{a}$ Sukhothai Thammathirat Open University, Chaengwattana Road, Pakkret, Nonthaburi 11120, Thailand.
}

\begin{abstract}
CLMV countries, namely Cambodia, Laos, Myanmar and Vietnam, are potential overseas markets for Thai contractors. Since the CLMV countries are in the developing stage, there are many construction and infrastructure projects emerging in order to develop economic growth of those countries. Therefore, it is an opportunity for Thai contractors to enter the CLMV construction markets. The study aims 1) to study the conditions and factors underlying in the construction business and construction project management for Thai contractors who enter the CLMV countries, and 2) to establish the competitive construction management strategies that could be adopted by Thai contractors in the CLMV countries. This study is a qualitative research. The population is divided into 2 groups, one is the senior executives of Thai contractors who manage their construction projects in Laos or Myanmar, the other is the project owners or stakeholders in construction industry of the studied nations. Data collection instruments were the interview forms and data analysis used content analysis. Research findings revealed that the construction industry in CLMV countries are still in high demand of construction projects. Strengths of Thai contractors were time and quality management while weaknesses was price management. Therefore, Thai contractors should play their roles by using differentiation strategies and niche strategies.
\end{abstract}

(C) 2019 The Authors. Published by Budapest University of Technology and Economics \& Diamond Congress Ltd.

Peer-review under responsibility of the scientific committee of the Creative Construction Conference 2019.

Keywords: CLMV countries; competitive strategy; construction project; project management; Thai contractors.

\section{Introduction}

Investing in the overseas construction project is an alternative to Thai construction companies during the period of the domestic economic crisis. At the present, some of Thai construction companies have expanded their businesses to the global market especially in the CLMV countries namely Cambodia, Laos, Myanmar and Vietnam. CLMV countries are potential market for Thai construction business for not only a main contractor but also a subcontractor. Since CLMV countries are in the developing stage, construction project such as large scale infrastructure projects are still in high demand. This is an opportunity for Thai construction contractors to enter the construction market in the CLMV countries. However, the operation of construction projects in the CLMV countries has higher risks than in Thailand. Therefore, Thai contractor should establish their strategies in order to compete in the international market.

In addition to their domestic businesses, Thai construction companies, especially larger ones, are increasingly expanding their customer base into overseas' markets, in particular to the CLM (Cambodia-Laos-Myanmar) region due to these countries' rapid economic expansion and the concomitant development of their national infrastructure and built environment including, for example, road building and large-scale residential development. SMEs have the possibility of either working on smaller projects or sub-contracting for larger companies doing work such as restoration and finishing work on housing. Being able to take advantage of these openings depends on building partnerships with

*Corresponding author: Author email: thippawan.boo@stou.ac.th 
Thippawan Boonyaperm / Proceedings of the Creative Construction Conference (2019) 034

https://doi.org/10.3311/CCC2019-034

operators in the overseas' markets and developing relationships with larger Thai operators to sub-contract for or to use as a source of financing. [1]

It can be seen that the investment situation in the construction business of Thai entrepreneurs in the CLMV countries has good potential. Recently, there are a number of Thai contractors operating the construction projects in such countries. The increasing number of foreign contractors in the CLMV countries has generated wide interest in the competitive strategy in managing construction project effectively. Therefore, this study aims: 1) to study the conditions and factors underlying in the construction business and construction project management for Thai contractors who enter the CLMV countries; and 2) to establish the competitive construction management strategies that could be adopted by Thai contractors in the CLMV countries.

\section{Literature Review}

\subsection{The concept of competitive strategy}

The term of strategy is difficult to be defined and there are efforts found in many management texts to provide a clear definition. A strategy is also a set of rules for guiding decisions about organization behavior. It may be explicitly or implicitly, kept within the confines of the senior management team or pervading the organization to produce a sense of common direction. Two views have emerged on the nature of strategy. The first perspective views strategy as planning mode. A strategy is work out in advance, is explicit and it deals with the managers who develop a systematic and structured plan to meet objectives. The second perspective sees strategy as an evolutionary mode. From this viewpoint strategy evolves over time. It is not thought out and planned, but it is rather a stream of significant decisions. [2] Consequently, for the purpose of this research, strategy is defined as the determination of a basic long-term objectives and the adoption of courses of action and allocation of resources necessary to achieve the goals.

Developing a competitive strategy, a company must determine how the firm is going to compete; what its goals should be; and what policies are needed to carry out these goals. Thus, the competitive strategy of the company will be a combination of the goal for which the firm is striving, and the means by which it is seeking to get there. At a global level and beyond the articulation of a competitive strategy, two types of key factors determine the company's accomplishment: factors internal to the company and factors external to the company. [3] Internal factors can be grouped into two general areas include organization's strengths and weaknesses and personal values of an organization. While external factors can be divided into industries opportunities and threats and societal expectation.

\subsection{The five competitive forces}

The first fundamental determinant of a firm's profitability is industry attractiveness. Competitive strategy must grow out of a sophisticated understanding of the rules of competition that determine an industry's attractiveness. The ultimate aim of competitive strategy is to cope with and, ideally, to change those rules in the firm's favor. In any industry, whether it is domestic or international, produces a product or a service, the rules of competition are embodied in five competitive factors: the entry of new competitors, the threat of substitutes, the bargaining power of buyers, the bargaining power of suppliers, and the rivalry among the existing competitors. The five forces determine industry profitability because they influence the prices, costs, and required investment of firms in an industry.

\section{Conceptual framework for research}

From the review of concepts, theories, literature and related researches, this study expects to conclude the concept of competitive strategy of the contractor in managing construction projects by analysing external factors and internal factors.

External factors or demand conditions are related to competitive environment and societal environment. Competitive environment is the situation that the company must face in the organization operation, including industry competitors, threats of new entrants, bargaining power of buyers, bargaining power of suppliers, threats of substitute products or 
services, and stakeholder. Societal environment is beyond the business system. It depends on the current situation which affects the long-term business comprising economic, society and culture, technological and political factors.

Internal factors or production factors consists of company organizational management and human resources potential. Company organizational management include financial resources such as source of fund, financial management and construction project management technique such as integration management, scope management, time management, quality management, communication management, risk management, safety management, environment management and claim management. Human resources potential or personnel's highest capabilities was determined by motivation and characteristics of the executives.

To formulate contractor competitive strategy external factors and internal factors of Thai contractors were analysed to find out strengths, weaknesses, opportunities and threats of Thai contractors in the CLMV countries after that TOWS matrix concept has been applied to establish 4 competitive strategies, namely aggressive strategy (SO strategy), corrective strategy (WO strategy), defensive strategy (ST strategy) and proactive strategy (WT strategy). Aggressive strategy (SO strategy) is the most desirable situation of the organization that use strengths to take advantage of opportunities. Corrective strategy (WO strategy) is a situation in which the organizations use their opportunities to overcome and avoid threats. Defensive strategy (ST strategy) is a situation that arises from the environment that the organizations take advantage of their strengths to avoid real and potential threats. While proactive strategy (WT strategy) is the worst situation. The organizations are facing external threats and involving with many internal weaknesses, therefore they have to minimize their weaknesses and avoid the threats. The conceptual framework for research is shown in Fig.1.

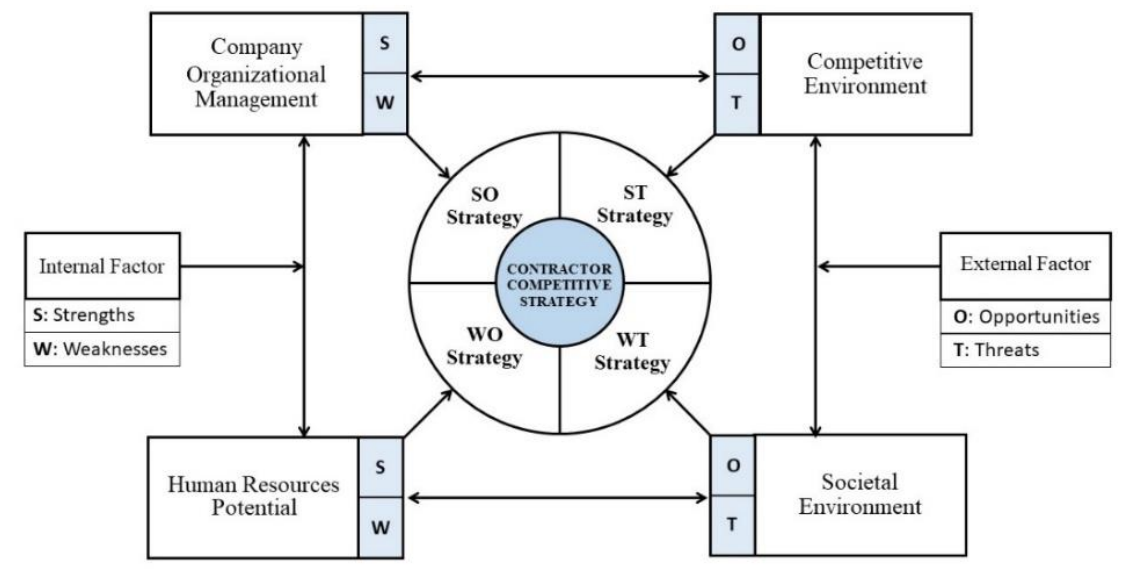

Fig. 1. Conceptual framework for research.

\section{Research Methodology}

This research is a qualitative research. The population is divided into 2 groups, one is the senior executives of Thai contractors who manage their construction projects in Laos or Myanmar, the other is the project owners or stakeholders in construction industry of the studied nations. The researcher collected data by using in-depth interviews. Data collection instruments were in the form of interview. Data analysis use content analysis.

\section{Results and Discussion}

\subsection{Conditions for Thai contractors in the construction project management in the CLMV countries}

Due to continuous economic growth of the CLMV countries, rapid urban development with an increasing number of construction and sub-contracting works has been emerging. As a result, CLMV countries gain significant interest from both domestic and foreign investors. In accordance with the report of the Export-Import Bank of Thailand, which states 
that after the Laos becomes an ASEAN member, it is an important turning point for the international trade of Laos to grow rapidly. [4] Moreover, after the general election and the establishment of a new government in Myanmar Union, the country's trade and investment become highly potential country for both trading and investment. [5] In addition, the investment promotion policies of CLMV countries also motivate Thai contractors to be interested in implementing construction projects in CLMV countries by special investment privileges.

Construction projects in Laos and Myanmar can be categorized into 2 types, private and public construction projects. The private construction projects are mostly residential buildings such as apartments, residential condominiums and commercial buildings such as hotel, shopping center, hospital, factory, etc. The public construction projects usually supporting the country's development, are infrastructure and energy projects such as dam, hydroelectric power plant, road and expressway. Either constructing those private or public ones in the CLMV countries, the contractors should examine the local building laws or regulations and the local process and procedure of building permission should be thoroughly studies.

\subsection{Factors of Thai contractors in the construction project management in the CLMV countries}

According to the conceptual framework of this research, there are external and internal factors that Thai construction contractors should consider when managing construction projects in the CLMV countries.

\section{External factors}

1) Competitive environment

- Industry competitors: According to the trade liberalization of the ASEAN Economic Community, CLMV are interesting countries for the foreign investors. Therefore contractors from various countries have been entering the CLMV construction market. It is found that in Laos, there are a large number of foreign contractors from Japan, China, Vietnam and Thailand while in Myanmar, most of foreign contractors come from Japan, China, Singapore, Vietnam, South Korea and Thailand. To compete with other foreign contractors, Thai contractor has been accepted and satisfied by the project owner in terms of quality standard and schedule control however the construction cost is relatively high, compared to the construction project managed by contractors from other countries.

- Threats of new entrants: Owing to the specific characteristics of construction industry, particularly a large amount of capital and financial support, the new entry rate of the entry-level contractors is relatively low. Similarly, those contractors either domestic or foreign companies, who already entered the CLMV construction market, have already invested a large amount of money on the construction business and, their investment takes a longer time to be paid off, so the exit rate is also relatively low.

- Bargaining power of buyers: The buyer in this context means the project owner that in this situation may have a high bargaining power. It is important for the contractors to understand the factors of consideration of the project owners when appoint a particular contractor.

- Bargaining power of suppliers: Construction materials and equipment costs are significant aspects in construction projects. The efficiently materials and equipment cost controlling could result in, more profit to the contractors. Most of the contractors use construction materials produced from their own country.

- Threats of substitute products or services: A number of factors are necessarily taken into account when the substitute products or services would be applied. For instance, the reliability and the financial status of the substitute contractor are concerned by the project owners in order to compare the different between each contractor before selection.

2) Social environment

- Politics and law: To operating construction project in CLMV countries, Thai contractors need to study the domestic laws, regulations and construction work procedures. The regulations and guidelines of each country may be varied times by times and sometimes they are subject to the government officers who implemented them.

- Economic: Economic conditions of the CLMV countries i.e. Laos and Myanmar has been positioned in the growth stage. Increasing number of infrastructure and building projects provide opportunities for Thai contractors to compete in these markets. The local governments of the CLMV countries may consider to ease some 
regulations or restrictions in order to motivate the overseas business sector and attract more foreign investing in the countries.

- Society and culture: Most of CLMV countries are Buddhism nations so, they are likely to share the similar values. However, it is necessary for the investors to learn about the local society and culture of each country. The contractors in the planning and management of the construction project, cannot ignore these matters.

- Technology: As the interview with related parties, it is found that the development of construction technology in Laos and Myanmar is still inefficient. Therefore, they need to import technology, equipment, tools and machinery including raw materials and construction materials such as cement and steel bar from other countries, especially from Thailand.

\section{Internal factors}

1) Company organizational management

- Financial management: Traditionally, the Thai contractor, who enter to construct work in foreign countries such as Laos or Myanmar, needs an initial capital for various stages in the project management processes. As a result, a large amount of investment capital is needed for managing the construction project.

- Construction project management technique: After bidding process and contract signing, the contractors will review the construction plan before the construction begins. Considering the construction technique, this study found that construction techniques are not the problems for Thai contractors. The construction quality of Thai contractors has achieved the construction standards which was accepted by the project owners in the CLMV countries. Customers are very satisfied with the quality of Thai contractors' work.

2) Human resources potential

- Motivation : Thai contractors who run the construction project in the CLMV countries mostly employ Thai workforce. The employment of Thai workforce in order to work in the foreign countries should consider reasonable motivation for the workers, mostly in term of compensation. In addition, a challenging work in the assigned project is seen as one of an incentive for new generations' workforce.

- Personnel characteristics: Thai contractors mostly arrange the construction project management team such as engineers, architects and technician from Thailand while the unskilled labor depends on each project. Sometimes they uses Thai labors but some projects they hired the local labors.

\subsection{SWOT Analysis of Thai contractors in the construction project management in the CLMV countries}

In managing construction projects, Thai contractors in the CLMV countries should begins with the analysis of the internal environment (strengths and weaknesses) and external environment (opportunities and threats) as shown in Table 1.

Table 1. SWOT analysis of Thai contractors in construction project management in the CLMV countries

\begin{tabular}{l} 
Strengths (S) \\
\hline S1. Thai contractors are recognized for qualified construction work. \\
S2. Thai contractors have sufficient capability to work in the \\
international market especially in ASEAN countries. \\
S3. Thai contractors use construction materials as identified in \\
construction drawings and specifications. \\
S4. The construction materials produced from Thailand are \\
accepted as qualified products. \\
S5. Thai contractors adopt the advanced construction technology \\
which was accepted by most project owners.
\end{tabular}

W1. The operation cost of Thai contractors is relatively high.

W2. The construction materials cost is relatively high, due to the additional operation cost and risk management cost.

W3. The labor cost of Thai contractor is higher than local contractors or contractors in some countries.

W4. Lack of funding and financial support.

W5. Lack of language skills especially English, local language. 
Table 1. (continued)

\begin{tabular}{|c|c|}
\hline Strengths (S) & Weaknesses (W) \\
\hline $\begin{array}{l}\text { S6. Thai contractors have more experience in a variety of } \\
\text { construction types than the local contractors. }\end{array}$ & W6. Lack of communication skills and working command. \\
\hline $\begin{array}{l}\text { S7. Thai contractors have high operating standards and systematic } \\
\text { construction management. }\end{array}$ & $\begin{array}{l}\text { W7. Lack of the motivation for Thai workforce to work in the } \\
\text { CLMV countries. }\end{array}$ \\
\hline $\begin{array}{l}\text { S8. Some of large scale Thai contractors have a chance to build a } \\
\text { networking with local parties in CLMV countries to create a } \\
\text { partnerships. }\end{array}$ & $\begin{array}{l}\text { W8. The opportunity of SME contractors to get a job is } \\
\text { difficult. If there is no network relationship with the local } \\
\text { project owner. }\end{array}$ \\
\hline Opportunities $(\mathrm{O})$ & Threats (T) \\
\hline $\begin{array}{l}\text { O1. The economic development policy of the CLMV countries } \\
\text { create the demand of construction projects by both public and } \\
\text { private sectors }\end{array}$ & $\begin{array}{l}\text { T1. International transportation systems are not convenient and } \\
\text { not qualified as international standards. }\end{array}$ \\
\hline $\begin{array}{l}\text { O2. The establishment of AEC creates more opportunities in both } \\
\text { construction projects and construction materials markets. }\end{array}$ & T2. Local laws and regulations has been frequently changed. \\
\hline $\begin{array}{l}\text { O3. International financial support, assistance and international } \\
\text { trade privileges for developing countries. }\end{array}$ & $\begin{array}{l}\text { T3. The process of requesting permission from government } \\
\text { agencies is complicated and unclear. }\end{array}$ \\
\hline $\begin{array}{l}\text { O4. Joint venture with foreign countries especially ASEAN } \\
\text { countries will strengthen the capability of Thai contractors. }\end{array}$ & $\begin{array}{l}\text { T4. The process of construction building permission have } \\
\text { various contact organization. }\end{array}$ \\
\hline $\begin{array}{l}\text { O5. Development of industrial zones and Special Economic Zones } \\
\text { (SEZs) to support foreign investment. }\end{array}$ & $\begin{array}{l}\text { T5. The banking system is still not standardized and procedures } \\
\text { are quite complicated. }\end{array}$ \\
\hline $\begin{array}{l}\text { O6. Creating of other industrial developments related to the } \\
\text { construction industry such as material production, logistics. }\end{array}$ & $\begin{array}{l}\text { T6. Limitation of basic infrastructure systems. Many } \\
\text { transportation networks are under developed. }\end{array}$ \\
\hline O7. Proximity to the boundary checkpoints. & T7. Lack of skilled labor. \\
\hline O8. Abundant natural resources in the CLMV countries. & T8. Obstacles from natural climate to construction work. \\
\hline
\end{tabular}

\subsection{Competitive Strategy of Thai contractors in the construction project management in the CLMV countries}

Based on the analysis of strengths, weaknesses, opportunities and threats of Thai contractors in the CLMV countries which using TOWS matrix concept, 4 competitive strategies are established, namely aggressive strategy (SO Strategy), corrective strategy (WO Strategy), defensive strategy (ST Strategy) and proactive strategy (WT Strategy).

Table 2. Competitive strategies of Thai contractors in the construction project management in the CLMV countries

\begin{tabular}{|c|c|c|c|}
\hline & SO Strategy & & ST Strategy \\
\hline S1O1 & $\begin{array}{l}\text { Selection of specific construction projects based on } \\
\text { working experience }\end{array}$ & S5T5 & $\begin{array}{l}\text { Bidding for the project with the project owner who } \\
\text { have reliable background and financial credibility. }\end{array}$ \\
\hline $\mathrm{S} 2 \mathrm{O} 2$ & $\begin{array}{l}\text { Management of construction project by employing } \\
\text { workforce in technical level and skilled workers from } \\
\text { Thailand while hiring unskilled workers from local area. }\end{array}$ & S5T7 & $\begin{array}{l}\text { Implementation of standardised innovation and } \\
\text { working system to develop the standard of local } \\
\text { workers }\end{array}$ \\
\hline $\mathrm{S} 3 \mathrm{O} 7$ & $\begin{array}{l}\text { Using of construction materials from Thailand, by } \\
\text { purchasing and delivering with the logistics system } \\
\text { through the checkpoints of the border where is the } \\
\text { nearest to construction site. }\end{array}$ & S6T7 & $\begin{array}{l}\text { Selection of projects that Thai contractors have } \\
\text { competitive technology support while local contractors } \\
\text { lack of experience. }\end{array}$ \\
\hline \multirow[t]{2}{*}{ S7O6 } & $\begin{array}{l}\text { Adjustment of the procurement system for materials and } \\
\text { equipment by transferring the responsibility of } \\
\text { purchasing materials to the project owners }\end{array}$ & S8T3 & $\begin{array}{l}\text { Forming investment alliances, including the project } \\
\text { owner, investor, distributor, }\end{array}$ \\
\hline & WO Strategy & & WT Strategy \\
\hline W3O6 & $\begin{array}{l}\text { Operating subcontract work with specialization skills, } \\
\text { such as building mechanical and electrical systems }\end{array}$ & W3T7 & $\begin{array}{l}\text { Cost reduction by hiring local workers or foreign } \\
\text { workers in that country }\end{array}$ \\
\hline W8O4 & $\begin{array}{l}\text { Building network and relationships with investors of } \\
\text { each country in order to promote the organization }\end{array}$ & W7T7 & $\begin{array}{l}\text { Creating incentives other than increasing remuneration } \\
\text { for professional personnel }\end{array}$ \\
\hline
\end{tabular}


Thippawan Boonyaperm / Proceedings of the Creative Construction Conference (2019) 034 https://doi.org/10.3311/CCC2019-034

Table 2. (continued)

\begin{tabular}{llllll}
\hline \multicolumn{3}{c}{ WO Strategy } & & & WT Strategy \\
\hline W5O2 & $\begin{array}{l}\text { Development of language skills for better } \\
\text { communication }\end{array}$ & W8T4 & $\begin{array}{l}\text { Local partnership to create an alliance and network for } \\
\text { investment before entering the market }\end{array}$ \\
W6O2 & $\begin{array}{l}\text { Development of management skills for improving } \\
\text { productivity }\end{array}$ & W1T1 & $\begin{array}{l}\text { Curriculum development for improving construction } \\
\text { skills in construction sites in foreign countries }\end{array}$ \\
\hline
\end{tabular}

Normally, formulating competitive strategies depend on the situation of the organization in each period. By analyzing the internal and external environment of construction project management in the CLMV countries, it is able to determine the competitive strategies of Thai contractors which can be discussed as a strategy for managing construction projects in CLMV countries as follows;

Competitive strategies consists of cost leadership strategy, differentiation strategy and focus or niche strategy. [6] For the use of the cost leadership strategy would be difficult for Thai contractors because the results from this study found that in the CLMV countries, Thai contractors have higher construction costs than domestic contractors, because of labor costs and construction material costs, operating fees, as well as the provision of various risks. In addition, there are competitors in the construction market in the CLMV countries, which are contractors from China with low construction costs. According to Wang, Y. \& Zuo, J. [7], it is concluded that China's international construction companies use low-cost labor and labor-intensive and take the advantages from low cost of construction materials, especially those which are produced in China.

From the analysis of this study, it was found that Thai contractors are outstanding in the quality of work, using standard quality of construction materials, with high technology and have working experience in large projects. Therefore differentiation strategy should be applied in managing construction projects in this CLMV countries, as follows;

- Managing specific construction project based on direct working experience.

- Operating construction project that have specialized technologies.

- Building relationships with customers by providing quality construction project management services.

- Branding strategies for better awareness and royalty.

Since the construction sector consists of various kinds of work, such as construction work, sub-contracting, building system, consulting work, construction project manager, procurement of material and equipment, logistics system, etc. Focus or niche strategy should be applied in order to reach target customers directly, as follows;

- Working as subcontractor in specific areas such as building systems, or particular work that requires specific techniques that local contractors do have enough competency.

- Recruiting technical level workforce and skilled labors from Thailand while hiring the unskilled labor from local areas.

- Transferring the responsibility of material procurement to the project owner.

- Operating logistics system for construction materials and equipment.

\section{Acknowledgements}

This study is based upon research of the competitive strategy of Thai contractor in construction project management in the CLMV countries: A case study of the Lao People's Democratic Republic (LPDR) and the Republic of the Union of Myanmar [8] which was supported by a grant from Sukhothai Thammathirat Open University. The author would like to express my sincere gratitude to all of the correspondence interviewee who provided insight and expertise that greatly assisted the research. 
Thippawan Boonyaperm / Proceedings of the Creative Construction Conference (2019) 034

https://doi.org/10.3311/CCC2019-034

\section{References}

[1] Toomwongsa, N. Construction contractor. Thailand industry outlook 2017-2019. Retrieved on March 1, 2019 from www.krungsri.com/bank/getmedia/546a9e27-9f1d-4302-b0ff-e5830ee1bf18/IO_Construction_Contractor_2017_EN.aspx

[2] Langford, D. \& Male, S. Strategic Management in Construction. $2^{\text {nd }}$ ed. Hoboken: John Wiley \& Sons, 2008.

[3] Krippaehne, R.C., McCullouch, B.G. \& Vanegas, J.A. Vertical Business Integration Strategies for Construction. Journal of Management in Engineering, April 1992, pp. 153-166. https://doi.org/10.1061/(ASCE)9742-597X(1992)8:2(153)

[4] EXIM Thailand, (2016). Trade and Investment Guidebook: Lao PDR. Retrieved on 8 August 2017, from

http://www.exim.go.th/doc/newsCenter/47568.pdf

[5] EXIM Thailand, (2016). Trade and Investment Guidebook: Myanmar. Retrieved on 8 August 2017, from

http://www.exim.go.th/doc/newsCenter/47570.pdf

[6] Porter, M.E. Competitive Strategy: Techniques for Analyzing Industries and Competitors, New York: The Free Press: A division of Macmillan Publishers, 1980

[7] Wang, Y. \& Zuo, J. A Competitiveness Analysis on Chinese Construction Companies in the Global Market Using Diamond Model. Retrieved on 26 September 2017, from http://ieeexplore.ieee.org/document/5998597/?reload=true, 2011.

[8] Boonyaperm, T. The competitive strategy of Thai contractor in construction project management in the CLMV countries: A case study of the Lao People's Democratic Republic (LPDR) and the Republic of the Union of Myanmar, (in Thai). Sukhothai Thammathirat Open University, Nonthaburi, 2018. 